This item was submitted to Loughborough's Research Repository by the author.

Items in Figshare are protected by copyright, with all rights reserved, unless otherwise indicated.

\title{
The implications of an invasive species on the reliability of macroinverterbrate biomonitoring tools used in freshwater ecological assessments.
}

\section{PLEASE CITE THE PUBLISHED VERSION}

http://dx.doi.org/10.1016/j.ecolind.2015.11.051

\section{PUBLISHER}

(C) Elsevier

\section{VERSION}

AM (Accepted Manuscript)

\section{PUBLISHER STATEMENT}

This work is made available according to the conditions of the Creative Commons Attribution-NonCommercialNoDerivatives 4.0 International (CC BY-NC-ND 4.0) licence. Full details of this licence are available at: https://creativecommons.org/licenses/by-nc-nd/4.0/

\section{LICENCE}

CC BY-NC-ND 4.0

\section{REPOSITORY RECORD}

Mathers, Kate L., Richard P. Chadd, Chris A. Extence, Stephen P. Rice, and Paul J. Wood. 2019. "The Implications of an Invasive Species on the Reliability of Macroinverterbrate Biomonitoring Tools Used in Freshwater Ecological Assessments.". figshare. https://hdl.handle.net/2134/19806. 
1 The implications of an invasive species on the reliability of macroinverterbrate biomonitoring tools 2 used in freshwater ecological assessments.

3 Authors: Kate. L. Mathers ${ }^{1}$, Richard. P. Chadd ${ }^{2}$, Chris. A. Extence ${ }^{2}$, Stephen. P.Rice ${ }^{1}$, Paul. 4 J. Wood'.

5

$6{ }^{1}$ Department of Geography, Centre for Hydrological and Ecosystem Science, Loughborough 7 University, Loughborough, UK.

$8 \quad{ }^{2}$ Environment Agency, Spalding, U.K.

9

10

11

Author for Correspondence

Kate Mathers

Centre for Hydrological and Ecosystem Science

Department of Geography

Loughborough University

Loughborough Leicestershire

LE11 3TU

UK

K.mathers@lboro.ac.uk 
The implications of an invasive species on the reliability of macroinvertebrate biomonitoring tools used in freshwater ecological assessments.

Mathers, K.L., Chadd, R.P, Extence, C.A, Rice, S.P, and Wood, P.J.

\section{Abstract}

Invasive species represent one of greatest threats to aquatic biodiversity globally and are widely acknowledged to be instrumental in modifying native community structure. Despite this, little is known about how the increasing range expansion of invasive taxa may affect routine biomonitoring tools widely employed to measure or quantify environmental quality in lotic systems. This study examined the impact of an invasive freshwater crayfish on commonly employed riverine macroinvertebrate biomonitoring tools (scores and indices) designed to respond to a range of stressors. Data from long term monitoring sites on both 'control' and invaded rivers in England were examined to assess changes to biomonitoring scores following invasion by signal crayfish (Pacifastacus leniusculus). Results indicate that routine biomonitoring tools used to quantify potential ecological stressors which are weighted by abundance, such as the Lotic-invertebrate Index for Flow Evaluation (LIFE) score and Proportion of Sedimentsensitive Invertebrates (PSI), were subject to significant inflation following invasion. In contrast, indices based simply on the presence of taxa, such as the Average Score Per-Taxon (ASPT - a derivative of BMWP), displayed no changes compared to control rivers; or in the case of the Biological Monitoring Working Party Score (BMWP), NTAXA and EPT richness, no consistent pattern following invasion. Season had a significant effect on the interaction of crayfish and LIFE and PSI scores. Autumn samples were subject to statistical inflation following crayfish invasion whilst Spring samples exhibited no significant change. The results suggest that care should be taken when interpreting routine macroinvertebrate biomonitoring data where non-native crayfish are present, or in instances where their presence is suspected.

Keywords. non-native taxa, crayfish, macroinvertebrate, seasonal sampling, WFD, biological monitoring. 


\section{Introduction}

Invasive species are considered to be one of the greatest threats to global biodiversity (Simberloff et al., 2013). The extent of biological invasions has increased rapidly over the last century and it is likely that this rate will continue in the future (Pysek and Richardson, 2010). The translocation of non-native taxa can have significant and far reaching implications for the functioning of invaded ecosystems including habitat modifications, acting as vectors in the transmission of disease, and altering assemblage composition through predation and resource competition (Manchester and Bullock, 2000). The spatial and biological implications of invasions are driven and influenced by natural and anthropogenic global environmental change (Lapointe et al., 2012). Anthropogenic modifications are altering the structure of many aquatic ecosystems (Friberg, 2014) and biomonitoring programmes that assess the status of freshwater water bodies have become an essential means of monitoring and evaluating such pressures (Buss, 2015).

Benthic macroinvertebrates are one of the most commonly employed freshwater groups globally (Carter et al., 2006) and in Europe are designated as one of the biological quality elements employed in the implementation of the EU Water Framework Directive (WFD; EU, 2000). The occurrence of indicative aquatic invertebrate taxa and assemblages based upon functional traits and life histories have enabled the development of a multitude of biomonitoring tools used for the identification and quantification of a range of anthropogenic disturbances and stressors (Bonada et al., 2006). However, species expansion, in particular invasive species, may significantly compromise the use of aquatic macroinvertebrates as bioindicators (MacNeil et al., 2013). Selective predation by many invasive taxa such as crayfish (e.g Procambarus clarkii, Orconectes limosus; Pacisfastcus leniusculus) is likely to modify communities (Gheradi and Acquistapace, 2007; Ercoli et al., 2015) and may thereby reduce the effectiveness of commonly employed biomonitoring indices to accurately characterise the pressures they were designed to assess.

Crayfish are one of the largest freshwater invertebrates, typically dominating the biomass of benthic communities where they occur (Momot, 1995, Holdich, 2002). They are widely considered to be keystone species in both lotic and lentic habitats due to their size, population density and functional role in the ecosystem (Stenroth and Nyström, 2003). Invasive crayfish have been widely documented to reduce the biomass and richness of other aquatic macroinvertebrates and macrophytes (Twardocleb et al., 2013; Ercoli et al., 2015). Consequently, their introduction may have substantial effects on aquatic environments and communities. Although it is widely acknowledged that invasive crayfish species may be instrumental in modifying freshwater invertebrate community structure, little attention has been given to whether these potential community modifications influence the effectiveness of widely utilised biomonitoring tools. The aim of this study was to determine whether the performance of six commonly employed macroinvertebrate biomonitoring tools used in the routine ecological assessment and 
management of freshwaters have been affected following invasion of the signal crayfish (Pacisfastcus leniusculus) in English rivers.

\section{Methods}

2.1. Data

The main dataset employed in this study was derived from the Environment Agency of England and Wales 'BIOSYS' database. The data-set comprised 846 samples (380 and 467 from invaded and control samples respectively) with the majority of samples collected between 1990 and 2013 (three sites had data extending back to the 1970's and an additional four sites had data from the mid 1980's). Nine invaded sites and eight reaches where signal crayfish were absent throughout the record (control sites) from three English regions (East, North West and South East England) formed the basis of the analysis. The sites reflected different geological, hydrological and biogeographical characteristics regionally and were subject to no other significant anthropogenic stressors. Both native white-clawed crayfish (Austropotamobius pallipes) and other invasive invertebrate species were absent from the selected sites (with the exception of the longestablished gastropod Potamopyrgus antipodarum). $P$. antipodarum is widely distributed across most regions in England since its introduction over a century ago (Ponder, 1988) and is not considered to have any significant effects on freshwater invertebrate communities in most European streams (Murria, et al. 2008).

All benthic invertebrate samples were collected using the Environment Agency's standard sampling protocol for routine biomonitoring, comprising a 3-minute 'kick-sample', which encompasses all available habitats, and an additional 1-minute, detailed hand search using a standard FBA pattern pond net (Murray-Bligh, 1999). Each site has a season specific record of community composition; Spring (March -May, df 300), Summer (June-August, df 119), Autumn (September - November, df 352) and Winter, (December - February, df 75). Macroinvertebrates were recorded to either species or genus level. Diptera larvae were only resolved to family level and Hydracarina to order throughout the series. In total, 596 taxa were recorded.

Six standard biomonitoring indices of ecological and hydrological quality were derived for each sample. Three of these indicators are routinely used to assess water quality by the Environment Agency: the Biological Monitoring Working Party Score (BMWP; Chesters, 1980), the Number of BMWP-scoring families present (NTAXA) and the Average Score Per-Taxon (a derivative of BMWP). The Lotic Invertebrate index for Flow Evaluation (LIFE; Extence et al., 1999) which quantifies river flow pressures (e.g. low flows during drought, abstraction or impoundment pressures), and the Proportion of Sediment-sensitive Invertebrates (PSI; Extence et al., 2013), which provides a measure of community sensitivity to fine sediment were also calculated for each sample. For some samples PSI scores were unclassified reducing the sample number from 827 
to 745. All five of the above indices are widely employed by the Environment Agency to provide a measure of ecosystem health within lotic ecosystems. The final index employed was the richness of aquatic insect larvae within the orders Ephemeroptera, Plecoptera and Trichoptera (EPT richness) and is widely used internationally (e.g. Ligeiro et al., 2013; Tonkin et al., 2015). All indices were standardized by site (Z-scores) to control for natural variability associated with individual rivers.

\subsection{Data analysis}

Data were categorised into four groups: i) Control-before invasion, ii) Control-after invasion, iii) Invaded-before invasion, iv) Invaded-after invasion). For sites invaded by P.leniusculus the approximate date of invasion was determined based on the first occurrence in the historical faunal series. Detecting signal crayfish is difficult due to their high mobility (Gladman et al., 2010) and there are currently no methods of determining crayfish populations below a density of $0.2 \mathrm{~m}^{-2}$ (Peay, 2003). It is likely that the true detection limit is higher, probably approaching a density of $1.0 \mathrm{~m}^{-2}$ for the kick-net samples utilised in this study. As a result, it is important to acknowledge that signal crayfish may have been present at the study sites for a number of years prior to formal detection in biomonitoring samples. Also, routine sampling of crayfish populations is not a standard practice following invasion, and it is likely that variations in population densities between sites over time will be present in the dataset.

Control sites were divided into two periods (before invasion and after invasion) based on the mean date of invasion for the respective region (1999 for East; 1997 for North West; and 2003 for South East). This provided a means of assessing whether there were temporal shifts in invertebrate community composition and bioindicators not associated with crayfish invasion. This factor was included in the analysis as previous long-term analyses of UK data sets have revealed changes in community composition associated with drought (Monk et al., 2008), channel morphology modifications (Dunbar et al., 2010) and improvements in water quality (Durance and Ormerod, 2009).

To assess the potential influence of crayfish invasion on the biomonitoring indices, Generalised Linear Models (GLMs) were fitted to each metric. To enable a GLM to be fitted to the data, Zscores were normalised to positive values prior to analysis. This standardised the indices, making them comparable with each other, without modifying the variance or trends within the series. Models were fitted using the glm function in R Version 3.1.2 (R development Core Team, 2014). Inspection of the Akaike's Information Criteria (AIC) indicated that a Gaussian error distribution and identity link was the most suitable structure. Only significant terms were included in the final model and were examined using the drop function. For each index, a GLM was fitted which encompassed all available data. To assess the effect of crayfish on indices, the significance of the interaction term (time $x$ treatment) was examined. To determine any seasonal effects GLMs 
were fitted to indices based on Spring and Autumn samples (df 300, and 352 respectively - 265 and 321 for PSI). Temporal changes in index scores were visualised and inspected via error plots in IBM SPSS Statistics (version 21, IBM Corporation, New York). Index scores were visualised on a river, region and global basis to identify and confirm the consistency of the trends.

\section{Results}

ASPT scores (derived from BMWP) demonstrated no significant changes following crayfish invasion, with both 'control' and invaded rivers demonstrating an increase in scores over time $\left(\mathrm{T}_{3,827}=-0.183, \mathrm{P}>0.05\right.$; Fig. 1a). BMWP, NTAXA and EPT richness displayed inconsistent responses following crayfish invasion when individual rivers and regions were considered; some rivers and regions displayed a decrease comparative to the 'control' rivers whilst others displayed increases (Figs. 1b, c \& d). Both LIFE and PSI displayed a significant elevation of scores following crayfish invasion compared to control sites. For both indices, the overall temporal trend of increasing scores was present in both 'control' and invaded streams, however the increases in invaded streams following invasion were determined to be statistically inflated $(T=3,827=3.905, P$ $<0.001$ and $\mathrm{T}=3,745=3.905, \mathrm{P}<0.001$ respectively; Figs. $1 \mathrm{e} \& \mathrm{f}$ ). When season was considered, LIFE and PSI scores displayed significantly inflated scores within invaded rivers for the autumn season $\left(T_{3,350}=2.906, P<0.005\right.$ and $T=3,321=4.529, P<0.001$ respectively; Figs. $2 a$ and $\left.b\right)$. In contrast no significant differences in the temporal trends between invaded and 'control' sites were identified for any of the biomonitoring scores for the spring sampling period $(P>0.05)$. All statistical significance values and measures of standard error for the Before-After-ControlInvaded interaction effect for each index and season (Spring and Autumn) are presented in Table 1.

\section{Discussion}

Results from this study indicate that the presence of signal crayfish has not significantly changed the effectiveness of the commonly utilized water quality indices, ASPT, NTAXA or BMWP, employed for EU WFD ecological assessment (Furse et al., 2006). ASPT displayed no significant differences among control or invaded streams, with a similar magnitude of increase in the score over time. BMWP, NTAXA and the biometric of EPT richness all demonstrated no consistent pattern in either control or invaded streams, between regions or between rivers in the same region. All four of these scores are based on records of presence only and do not incorporate any weighting for the abundance of the taxa contributing to the score (recorded at family level). Furthermore, BMWP, NTAXA and EPT richness are additive measures which may be influenced by habitat richness and sampling effort, and are inherently more variable than their numerical average typically suggests (Clarke et al., 2003). It is likely that should these metrics include abundance weightings in their future derivations (as in the case of the proposed BMWP / NTAXA replacement - the Whalley, Hawkes, Paisley \& Trigg metric; WHPT, WFD-UKTAG, 2014), then 
alterations to scores following invasion may occur and the resulting scores would need to be interpreted with this in mind. Moreover, the taxonomic resolution used in scoring may play a key role in determining crayfish invasion effects, with greater taxonomic level (genus or species level data), making identification of invasion effects more likely. Reduced taxa richness (number of taxa) has been observed in other studies associated with crayfish invasion (Crawford et al., 2006; Ruokonen et al., 2014), although the family level data used to derive the metric NTAXA did not identify any assemblage changes in the current investigation.

LIFE and PSI indices, which incorporate abundance weightings of the taxa contributing to their score, both displayed significantly inflated scores following crayfish invasion compared to control rivers. The application of the LIFE scores enables flow regime variability to be quantified based upon the flow requirements of invertebrate species (Extence et al., 1999). Aquatic invertebrate community composition following crayfish invasion has been reported to shift towards more mobile taxa adapted to faster flow velocities at the expense of slower, less mobile taxa (Parkyn et al., 1997). Studies have reported increasing or unaltered abundances or dominance of highly mobile and flow velocity sensitive Ephemeroptera larvae at sites where invasive crayfish are present (Usio and Townsend, 2004; Grandjean et al., 2011). The inflated LIFE scores recorded within invaded streams most likely reflects the greater mobility of the remaining flow sensitive taxa, characteristics which are likely to enhance their ability to evade crayfish predation (Peckarsky, 1996). Predator avoidance strategies, including enhanced locomotion and vertical migration to the waterline or into the river bed (Crowl and Covich, 1990; Haddaway et al., 2014), by some taxa could potentially lead to the inflation or depression of biomonitoring scores. The application of biological indicators typically assumes that the impacts of predation and competition within macroinverterbrate assemblages are minor relative to the environmental changes that the index was designed (and employed) to detect. It is likely that native predatory species have little effect on the performance of biomonitoring tools because the community is familiar with them. However, the invasion of a non-native 'alien species' into a waterbody may disrupt this natural equilibrium leading to changes in the performance of biomonitoring tools.

The PSI score was designed to identify the effect of fine sediment pressure (primarily deposition) based upon tolerance ranges of individual taxa (Extence et al., 2013). It appears that the inflated PSI and LIFE scores recorded in this study were influenced by the markedly reduced abundance of Gastropoda, Bivalvia and Hirudinea taxa. These are among the most widely documented prey items of crayfish and may be selectively or preferentially predated by crayfish in many lotic ecosystems (Dorn, 2013). Although the prevalence of some prey taxa are likely to decrease in the presence of invasive crayfish, there is limited evidence to suggest that they become locally extinct. Consequently, the inflated PSI and LIFE scores may represent a shift to a community dominated, by fine sediment and flow sensitive taxa through predation rather than a shift in flow 
regime or fine sediment present at a site. Future application and potential modifications to these indices should consider the potential effect of invasive species upon them. The use of these indices in their current form could be used to help identify sites subject to invasive taxa but may also lead to the misinterpretation of the stressors affecting water bodies if not identified. Given the variety of invertebrate biomonitoring tools available we recommend that, where feasible, a multimetric approach is employed in the ecological assessment of freshwater bodies. The application of individual metrics may not indicate pressures associated with the stressor it was designed to quantify, but when used in combination with other metrics derived in different ways (e.g. presence / absence data, total abundance or abundance weighted), may provide evidence to indicate the presence of an ecological stressor(s). Together with knowledge regarding the wider environmental and ecological context, this approach may help inform water resource and river managers of potential threats to the ecological status of freshwater bodies associated with the spread of invasive species.

When individual seasons were considered, no significant differences were recorded between control and invaded sites / rivers for the spring sampling period. Crayfish movement and growth is strongly regulated by water temperatures, with activity increasing with rising temperatures (Johnson et al., 2014). Spring samples typically occur when crayfish activity is at its minimum and consequently it is unsurprising that none of the indices were significantly affected at this time of year. In contrast, Autumn samples are usually collected at the height or toward the end of crayfish activity (notably directly after the breeding season); with inflated elevation of both the LIFE and PSI scores evident at invaded sites. It is therefore recommended, that routine biomonitoring samples collected in autumn need to be interpreted with caution if invasive crayfish are present or if their presence is suspected. Samples collected in spring were not determined to be significantly affected but should still be considered with caution. We also advise that those applying macroinvertebrate biomonitoring indices to identify environmental stressors or those developing new indices should be conscious of the potential influence that invasive species may have on the effectiveness of such tools, especially if abundance weightings are incorporated in their derivation.

\section{Acknowledgements}

KLM acknowledges the support of a Glendonbrook doctoral studentship and co-funding from the Environment Agency. Russ Barber, Judy England, Andy Goodwin, Katy Lee, Will Olsen and Mitch Perkins from the Environment Agency are thanked for kindly providing the data from the BIOSYS database to undertake the research. Advice provided by Alice Hiley was invaluable. We thank two anonymous reviewers for their helpful and constructive comments. 


\section{References}

Bonada, N., Prat, N., Resh, V.H., Statzner, B. 2006. Developments in aquatic biomonitoring: A comparative analysis of recent approaches. Annu. Rev. Entomol. 51, 495-523.

Buss, D.F., Carlise, D.M., Chon, T-S., Culp, J., Harding, J.S., Keizer-Vlek, H.E., Robinson, W.A., Strachan, S., Thirion, C., Hughes, R.M. 2015. Stream biomonitoring using macroinvertebrates around the globe: a comparison of large scale programs. Environ. Monit. Asess. 187, $4132-4153$.

Carter, J.L., Resh, V.H., Rosenberg, D.M., Reynoldson, T.B., 2006. Biomonitoring in North American Rivers: a comparison of methods used for benthic macroinvertebrates in Canada and United States, in: Ziglio, G., Flaim, G., Sillgardi, M. (Eds.) Biological Monitoring of Rivers. John Wiley: New York.

Chesters, R.K. 1980. Biological Monitoring Working Party. The 1978 national testing exercise. Department of the Environment. Water Data Unit, Technical Memorandum 19.

Clarke, R.T., Wright, J.F., Furse, M.T. 2003. RIVPACS models for predicting the expected macroinvertebrate fauna and assessing the ecological quality of rivers. Ecol. Model. 160, 219233

Crawford L. Yeomans W.E., Adams C.E. 2006. The impact of introduced signal crayfish Pacifastacus leniusculus on stream invertebrate communities. Aquat. Conserv. Mar. Freshw. Ecosyst, 16, 611-621.

Crowl T.A., Covich A.P. 1990. Predator-induced life-history shifts in a freshwater snail. Sci, 23, $949-951$.

Dorn, N.J. 2013. Consumptive effects of crayfish limit snail populations. Freshw. Sci. 32, 1298-1308.

Dunbar, M.J., Pederson, M.L., Cadman, D., Extence, C., Waddingham, J., Chadd, R., Larsen, S.E., 2010. River discharge and local-scale physical habitat influence macroinvertebrate LIFE scores. Freshw. Biol. 55, 226-242.

Durance, I., Ormerod, S.J., 2009. Trends in water quality and discharge confound long-term warming effects on river macroinvertebrates. Freshw. Biol. 54, 388-405.

Ercoli, F., Ruokonen, T.J., Erkamo, E., Jones, R.I. Hamalainen, H. 2015. Comparing the effects of introduced signal crayfish and native noble crayfish on the littoral invertebrate assemblages of boreal lakes, Freshw. Sci. 34, 555-563.

European Union. 2000. Directive 2000/60/EC of the European Parliament and of the Council of 23 October 2000 establishing a framework for Community action in the field of water policy. Off. J.Eur. Communities. L327, 1-72.

Extence C.A., Chadd, R.P., England, J., Dunbar, M.J., Wood, P.J., Taylor, E.D. (2011). The assessment of fine sediment accumulation in rivers using macro-invertebrate community response. River Res. Appl. 29, 17-55.

Extence, C.A., Blabi, D.M., Chadd, R.P., 1999. River flow indexing using British benthic macroinvertebrates: A framework for setting hydroecological objectives. Regul. Rivers: Res. Manag. 15, 543-574.

Friberg, N. 2014 Impacts and indicators of change in lotic ecosystems, WIRES. Water. 6, 513-531.

Furse, M.T., Herin, D., Moog, O., Verdonshot, P., Johnson, R.K., Brabec, K., Gritzalise, K., Buffagni, A., Pinto, P., Friberg, N., Murry-Bligh., J., Kokes, J., Alber, R., Usseglio- Polatera, P., Hasse, P., Sweeting, R., Bis, B., Szoszkiewicz, K., Soszka, H., Springe, G., Sporka, F., Krno, I. 2006. The Star project: context, objectives and approaches. Hydrobiol. 566, 3-29.

Gheradi, F., Acquistapace, P. 2007, Invasive crayfish in Europe: the impact of Procambarus clarkii on the littoral community of a Mediterranean lake, Freshw. Biol, 52, 1249-1259

Grandjean, F., Jandry, J., Bardon, E., Coignet, A., 2011. Use of Ephemeroptera as bioindicators of the occurrence of white-clawed crayfish (Austropotamobius pallipes). Hydrobiol. 671, 253-258.

Gladman, Z.F., Yeomans, W.E., Adams, C.E., Bean, C.W., Mccoll, D., Oleszewska, J.P., McGillivray, C.W., McCluskey, R. 2010. Detecting North American signal crayfish (Pacifastacus leniusculus) in riffles. Aquat. Conserv. Mar. Freshw. Ecosyst. 20, 588-594.

Haddaway N.R., Vielle D., Mortimer R.J.G., Christmas M., Dunn A.M. 2014 Aquatic macroinvertebrate responses to native and non-native predators. Knowl Manag. Aquat Ecosyst. 415: 10

Holdich D.M. 2002. Background and functional morphology. In: Holdich, D.M. (Ed.) Biology of Freshwater Crayfish. Blackwell Science Ltd, Oxford, UK.

Johnson, M.F., Rice, S.P., Reid, I., 2014. The activity of signal crayfish (Pacifastacus leniusculus) in relation to thermal and hydraulic dynamics of an alluvial stream, UK. Hydrobiol. 724, $41-54$.

Lapointe, N. W.R, Thorson, J.T., Angermeier. 2012. Relative roles of natural and anthropogenic drivers of watershed invasibility in riverine ecosystems, Bio. Inv. 14, $1931-1945$.

Ligeiro, R. Hughes, R.M., Kaufmann, P.R., Macedo, D.R., Firmianoa, K.R., Ferreiraa, W.R., Oliveiraa, D., Meloe, A.S., Callistoa, M. 2013. Defining quantitative stream disturbance gradients and the additive role of habitat variation to explain macroinvertebrate taxa richness. Ecol. Indic. 25, 45-57

MacNeil, C., Boets, P., Lock, K., Goethals, P.L.M. 2013. Potential effects of the invasive 'killer shrimp' (Dikerogammarus villosus) on macroinvertebrate assemblages and biomonitoring indices. Freshw. Biol. 58, 1717-182

Manchester, S.R., Bullock, J.M. 2010. The impacts of non-native species on UK biodiversity and the effectiveness of control. J. Appl. Ecol. 37, 845,864.

Momot, W.T., 1995. Redefining the role of crayfish in aquatic ecosystems. Rev. Fish. Sci. 3, 33- 63.

Monk, W.A., Wood, P.J., Hannah, D.M., Wilson, D.A., 2008 Macroinvertebrate community response to inter-annual and regional river flow regime dynamics. River Res. Appl. 24, 988-1001. 
Murray-Bligh, J. 1999. Procedures for Collecting and Analysing Macroinvertebrate Samples BT0001. The Environment Agency, Bristol; 176.

Murria C. Bonada N., Prat N. 2008. Effects of the invasive species Potamopyrgus antipodarum (Hydrobiidae, Mollusca) on community structure in a small Mediterranean stream. Arch.Hydrobiol, 171, 131-143.

Parkyn, S.M., Rabeni, C.F., Collier, K.J., 1997. Effects of crayfish (Paranephrops planifrons: Parastacidae) on in-stream processes and benthic faunas: a density manipulation experiment. N.Z.J. Mar. Freshw. Res. 31, $685-692$.

Peay S., 2003. Monitoring the White-clawed Crayfish, Austropotamobius pallipes. Conserving Nature 2000 Rivers, Monitoring Series No. 1. English Nature, Peterborough, 52pp.

Peckarsky B.L., 1996. Alternative predator avoidance syndromes in stream-dwelling mayflies. Ecol. 77, 1888-1905.

Ponder W., 1988. Potamopyrgus antipodarum- A molluscan coloniser of Europe and Australia. J. Mollusc.Stud, 54, 271-285.

Pysek, P., Richardson, D.M., (2012) Invasive Species, Environmental Change and Management, and Health. Annu. Rev. Environ. Resour. 35, 25-55.

Ruokonen T.J. Karjalainen J., Hamalainen H. 2014 Effects of an invasive crayfish on the littoral macroinvertebrates of large boreal lakes are habitat specific. Freshw. Biol, 59, 12-25.

Stenroth, P., Nyström, P. 2003. Exotic crayfish in a brown water stream: effects on juvenile trout, invertebrates and algae. Freshw. Biol. 48, 466-475.

Simberloff, D., Martin, J. Aronson J.-L., Courchamp, F., Galil, B., Garcia-Berthou, E., Genovesi, P., Maris, V., Pascal, M., Pysek, P., Sousa, R., Tabacchi, E., Vila, M., Wardle, D., 2013 Impacts of biological invasions-what's what and the way forward. Trends. Ecol. Evol, 28, 58- 66.

Tonkin J.D., Shah D.N., Kuemmerlen M., Li F., Cai Q., Haase, P., Jähnig, S.C. 2015. Climatic and catchment-scale predictors of Chinese stream insect richness differ between taxonomic groups. PLoS ONE 10(4): e0123250.

Twardocleb, L.A., Olden, J.D., Larson, E.R., 2013. A global meta-analysis of the ecological impacts of non-native crayfish. Freshw. Sci. 32, 1367-1382.

Usio, N., Townsend, C.R., 2004. Roles of crayfish: Consequences of predation and bioturbation for stream invertebrates. Ecol. 85, 807-822.

Water Framework Directive, United Kingdom Advisory Group. 2014. Invertebrates (General Degradation) Whalley, Hawkes, Paisley \& Trigg (WHPT) metric in River Invertebrate Classification Tool (RICT), UKTAG River Assessment Method, Benthic invertebrate Fauna report. UKTAG.

\section{List of Figures}

Fig. 1. Macroinvertebrate biomonitoring indices (mean $\pm 95 \% \mathrm{Cl}$ ) recorded for each before, after, invaded and control factor in East, South East and North West England; a) ASPT; b) BMWP; c) NTAXA ; d) EPT richness; e) PSI and; f) LIFE; Black solid = Before Invaded; Grey solid = After Invaded; Black dashed = Before Control and; Grey dashed = After Control. Metrics standardised to Z-scores.

Fig. 2. Macroinvertebrate biomonitoring indices (mean $\pm 95 \% \mathrm{Cl}$ ) recorded for each before, after, invaded and control factor for spring and Autumn samples from all three regions; a) LIFE and; $b$ ) PSI. Black solid = Before Invaded; Grey solid = After Invaded; Black dashed = Before Control and; Grey dashed = After Control. Metrics standardised to Z-scores. 

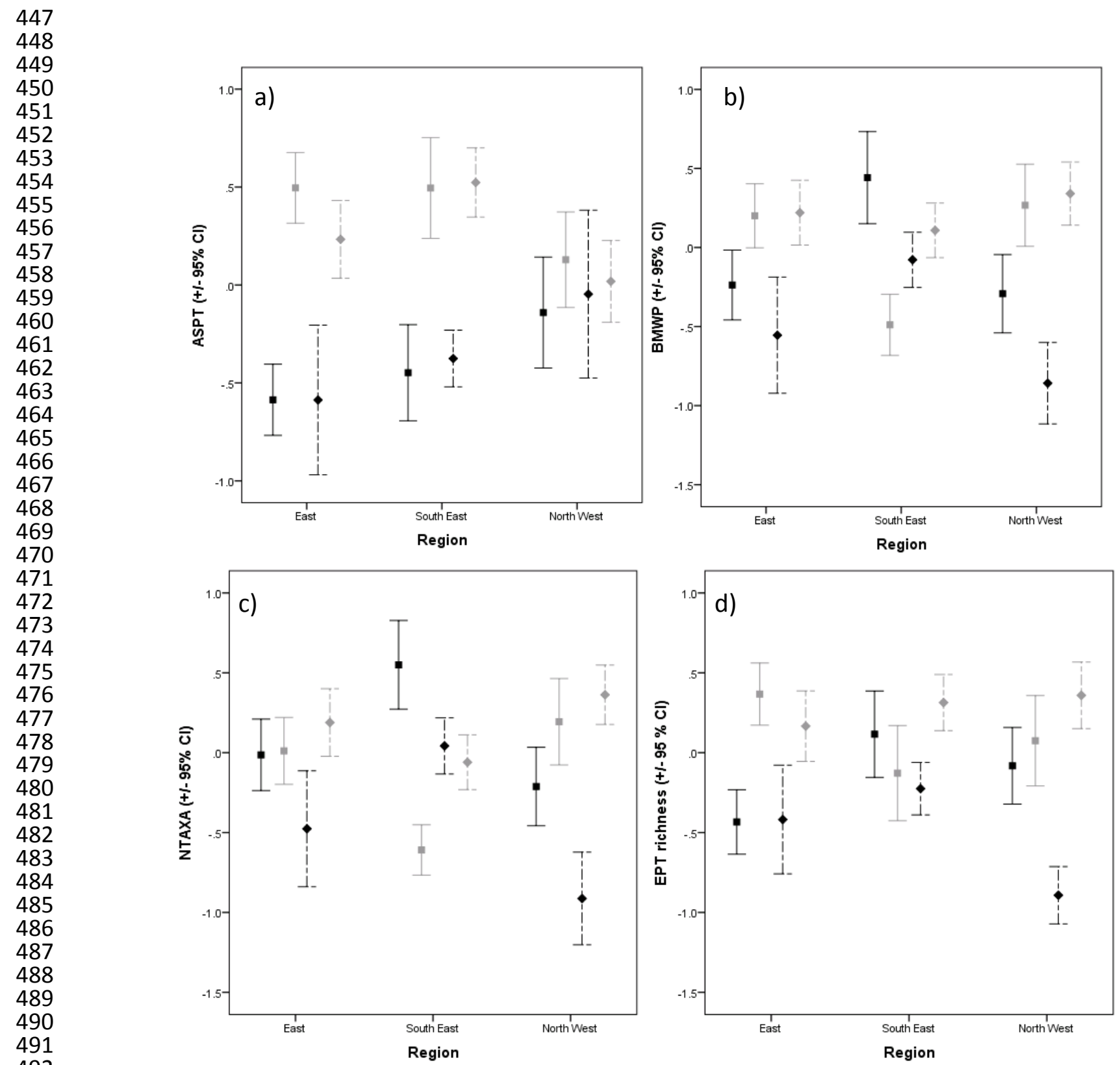

492

493

494

495

496

497

498

499

500

501

502

503

504

505

506

507

508

509

510

511

512

513
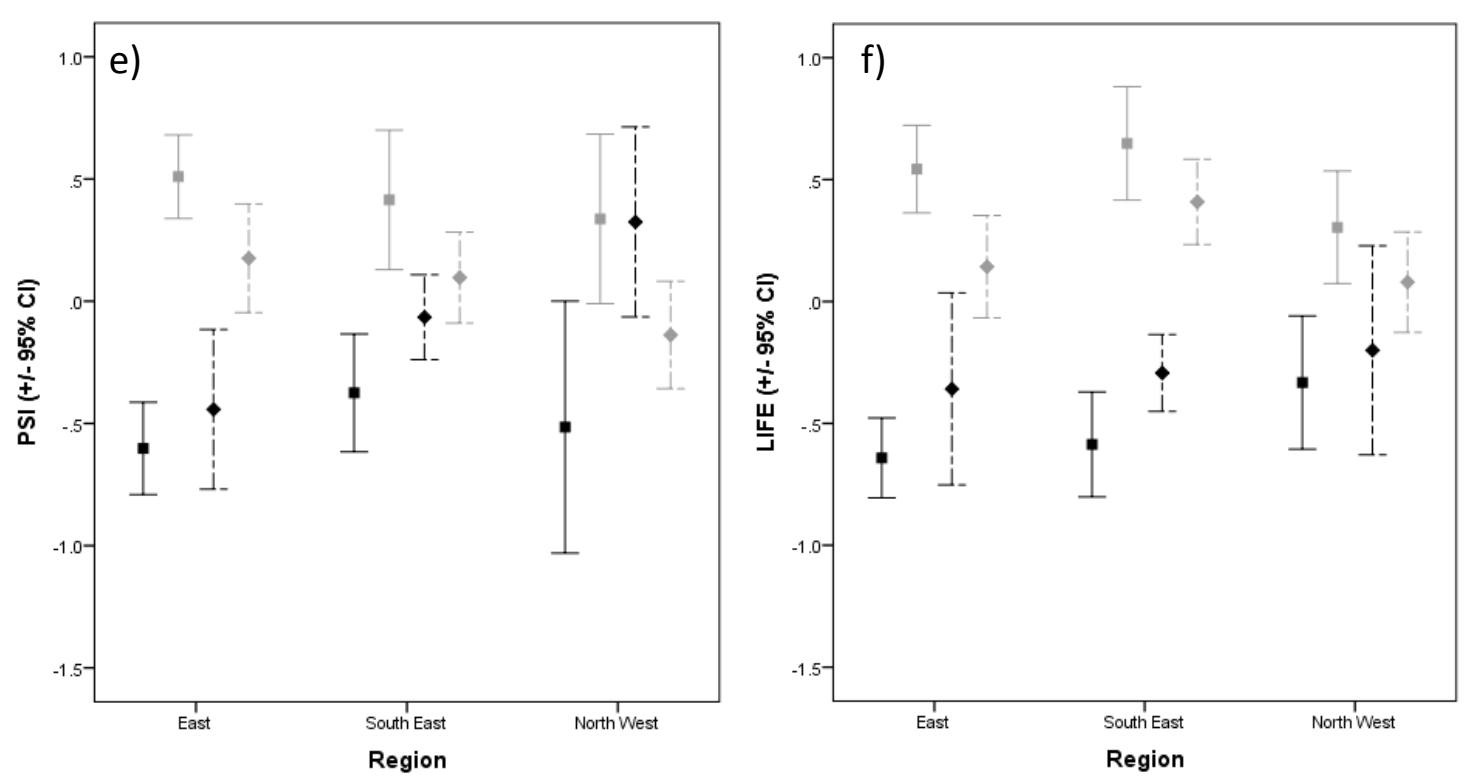

Figure 1 

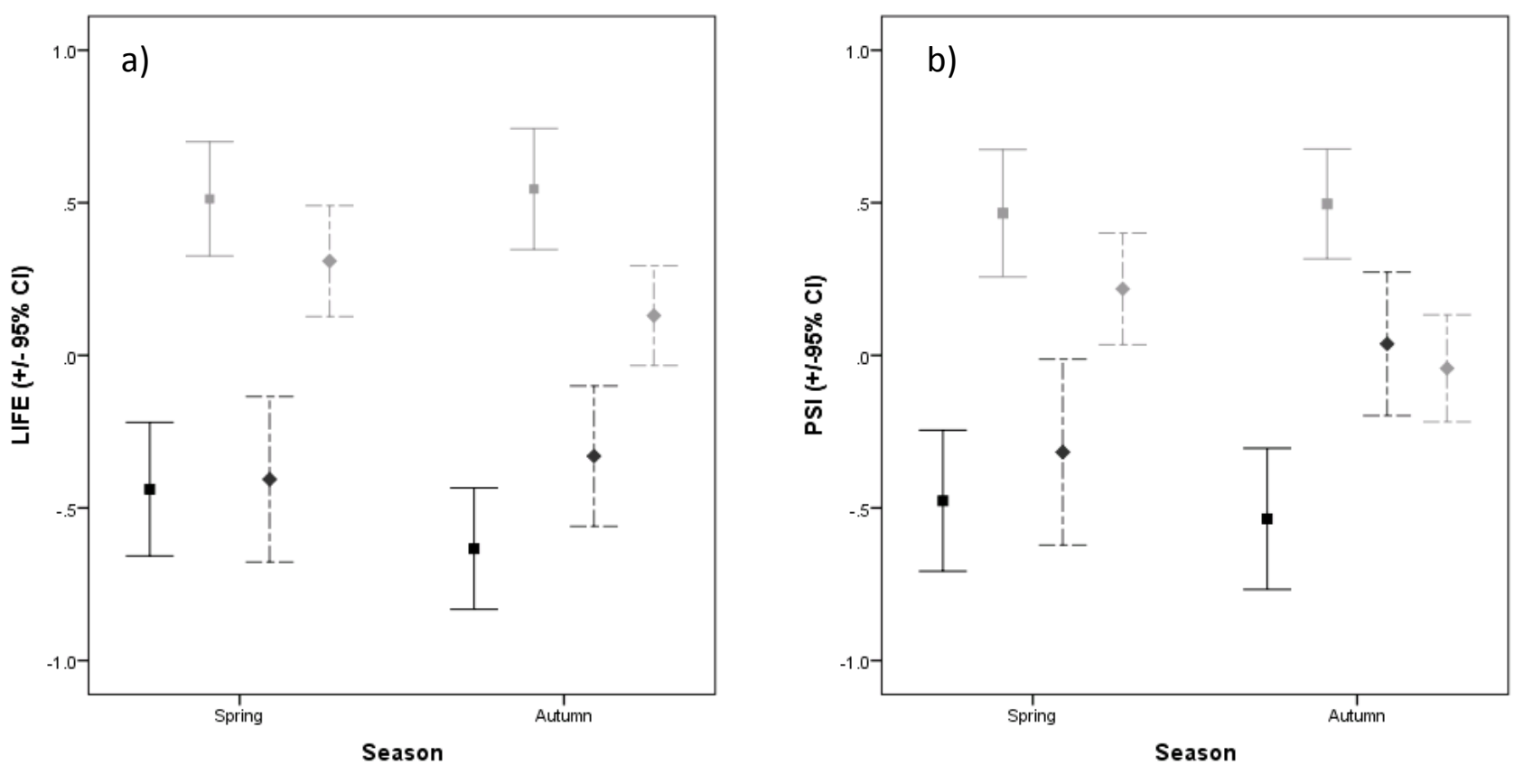

Figure 2

Table 1. Summary values for the Before-After-Invaded -Control interaction effects from the GLM for each bio-monitoring index

\begin{tabular}{|c|c|c|c|c|}
\hline & SE & T-Value & P-Value & Degree of sig \\
\hline \multicolumn{5}{|l|}{ All seasons } \\
\hline BMWP & 0.141 & -3.374 & $<0.001$ & $* * *$ \\
\hline ASPT & 0.135 & -0.183 & 0.855 & \\
\hline NTAXA & 0.148 & -4.188 & $<0.001$ & $* * *$ \\
\hline EPT richness & 0.139 & -3.121 & 0.002 & $* *$ \\
\hline LIFE & 0.134 & 3.905 & $<0.001$ & $* * *$ \\
\hline PSI & 0.150 & 5.239 & $<0.001$ & $* * *$ \\
\hline \multicolumn{5}{|l|}{ Spring } \\
\hline BMWP & 0.253 & -0.786 & 0.433 & \\
\hline ASPT & 0.244 & -0.008 & 0.994 & \\
\hline NTAXA & 0.248 & -0.692 & 0.489 & \\
\hline EPT richness & 0.266 & -1.513 & 0.131 & \\
\hline LIFE & 0.233 & 1.576 & 0.116 & \\
\hline PSI & 0.265 & 1.626 & 0.105 & \\
\hline \multicolumn{5}{|l|}{ Autumn } \\
\hline BMWP & 0.217 & -2.605 & 0.010 & $*$ \\
\hline ASPT & 0.200 & 0.569 & 0.570 & \\
\hline NTAXA & 0.224 & -3.280 & 0.001 & $* *$ \\
\hline EPT richness & 0.219 & -2.429 & 0.015 & $*$ \\
\hline LIFE & 0.212 & 2.906 & 0.004 & $* *$ \\
\hline PSI & 0.232 & 4.529 & $<0.001$ & $* * *$ \\
\hline
\end{tabular}

